\title{
Energy and the Three Levels of National Security: Differentiating Energy Concerns within a National Security Context
}

\author{
Phillip E. Cornell*
}

\section{Introduction}

The past several years have seen a renewed interest in the confluence of energy security and national security policy. Defining the intersection between such wideranging policy areas has been predictably inconsistent, and highly dependent on respective national and agent-based interests. At both national and multinational levels, conflicting objectives and definitions have driven confused attempts to develop singular "energy security" policies within an international security context. Since 2006, NATO has been engaged in a concerted if arduous and controversial process of defining the value the organization adds to the security environment. The new U.S. administration has put energy security front and center on its agenda, particularly in relation to foreign and security policy, but a confused interagency jumble has left many hands on the rudder of foreign energy policy. In the media as well as policy circles, cut-offs of Russian gas, Somali piracy, SCADA system vulnerabilities, terrorist attacks on Middle East pipelines, nuclear safety, and volatile gasoline prices have been too often lumped together.

This article thus returns to basics, and proposes to define energy security in a national security context using a rudimentary three-level model of national security itself. That is, national security as the functionality and success of security services at the primary level; as the functioning of critical domestic services at the secondary level; and as economic well-being and prosperity at the tertiary level. While imperfectly separating admittedly interrelated spheres of national security, such a model can begin the process of differentiating challenges and threats of energy insecurity within a national security discourse. In reality, of course, similar threat-types may have different impacts across those levels, and indeed the second part of this essay shows how a few such outcome-based threat categories (such as those that portend short-run catastrophe or those that cause price fluctuations) do so. The aim is to begin a process of prioritizing different types of energy disruptions on national security.

In the recent past, fears of energy insecurity have been stoked by a potent mix of rapidly rising oil and gas prices, increasingly nationalist and politicized energy policies, and greater reliance on a few foreign energy suppliers. And though en-

Phillip Cornell is a Senior Fellow and Director for International Initiatives at the NATO

School in Oberammergau, Germany. 
ergy price collapses in the autumn of 2008 may apparently grant a reprieve, they are likely to exacerbate the problem if the issue is pushed out of the public discourse in advance of a coming and sustained supply crunch in the middle of the next decade. In the wake of the August 2008 war in the South Caucasus, one of the most vociferous American contributors to the energy debate, Senator Richard Lugar, embarked on a two-week tour of the region where he reiterated calls made at the 2006 NATO Riga Summit and since to develop an "energy Article V," and for the Alliance to get tough on energy. Those statements, clearly aimed at a Russian target, were the latest in a string of warnings from policy makers and the media that confuse the relationship between national security, energy economics, and the instruments of security policy.

This article will therefore take the first steps towards disentangling the confluence of security and energy policy, differentiating the types of national vulnerabilities exposed by energy insecurity and using the three-tier construct discussed above to define the successive degrees to which they impact national security. Identifying the "threats" posed by energy insecurity can begin the process of clarifying the debate, and help to move away from the use of vague and multiply definable terms - such as "energy security" itself - to obfuscate a series of interrelated but separately complex problems. Having established and differentiated the threat patterns posed by energy insecurity, mitigation policies can be similarly differentiated and reduce the risk of exacerbating that insecurity through the misapplication of policy tools.

\section{Challenges to State Existence, Domestic Safety, and Economic Welfare}

That energy is critical to a state's security is self-evident. Some form of reliable energy supply has always been critical to keeping militaries moving-whether in the form of feed for pack animals, coal to transport Alfred von Schlieffen's paper troops from front to front by rail, or synthetic fuels to keep Messerschmitt fighter planes aloft during World War II when strategic disasters denied the Nazis access to crucial eastern oil fields.

But these are only the immediate examples of energy's role in national security at the primary level, that of maintaining the existence of the state. Military priorities and emergency rationing systems usually mean that the security services are the last sectors to be denied fuel in times of crisis, and such a level of depletion is hardly conceivable in the West today. That being said, the continued reliance of expeditionary military operations on enormous quantities of energy resources means that guaranteeing supply to and within an operational theatre is a primary concern. Also, rising fuel costs crowd out alternative forms of military investment and reduce overall functionality. Thus "military energy security" as such refers mainly to securing logistics chains and adjusting them to meet the needs of ongoing operations, as well as controlling overall energy costs and demand. 
At the secondary level of national security, energy is at the center of the "system of systems" that makes up a modern society's critical infrastructure. Electrical power drives everything from communications, transportation, and water distribution to the oil and gas systems that produce that power. Loss of energy production and distribution capacity - whether because of the destruction of power facilities or the severing of supply and distribution channels - can have debilitating effects that ripple throughout society, depending of course on the severity and duration of the interruption. Natural gas and electricity, which tend to be required at a moreor-less constant level of supply, represent particular vulnerabilities here.

At the tertiary level, energy security as it is traditionally defined requires that prices for the energy resources used by the public be "reasonable." From this standpoint, economic vitality in consumer countries is dependent on energy prices that do not drastically hamper productivity, restrict consumption, and drive inflation across the economy. At the same time, producers seek the highest level of prices possible without impeding long-term demand. The international public policy focus should thus be on price stability. Shocks can certainly be painful, as the West learned in the 1970s, producers learned in the 1980s, and as consumers of food, gasoline, and manufactured goods learned as recently as 2008. Indeed, while less deadly in the short and medium run, rising prices among consumers are the bridgehead to primary and secondary vulnerabilities - and how "reasonable" prices are is clearly a subjective matter that will depend on a variety of unique local and national conditions.

At each of these levels, different types of threats can put different infrastructures at risk and produce various undesired outcomes. The following sections of this article will elaborate on how energy impacts each of these levels, and then clarify how the tools of security policy may or may not be effective in addressing the wide range of threats posed by energy insecurity.

\section{Energy and Primary Security: Ensuring Military Functionality}

Energy products have always been treated as a special commodity. Today, of course, they are crucial to the functioning of society. But in practice, the main historical significance of energy lay in its military necessity.

Even before the advent of mechanized transport, Napoleon quipped that an army marched on its stomach. Indeed, the importance of feeding soldiers and pack animals to keep armies on the move reflected the importance of logistical supply chains and bio-energy resource provision to military mobility, a challenge that has existed since ancient times. But with increased reliance on steam shipping and then railroads for the movement of forces and materiel in the nineteenth century, more familiar energy resources (like coal) became strategic assets. At the same time, with the Industrial Revolution and the advent of "national" warfare brought on by the use of citizen armies after the French Revolution, the line between in- 
dustrial assets' importance to civilian economic life and to military operations began to blur. The more a national war machine is the product of its national production capacities, the more civil and economic targets in that nation will become critical to a war effort. No wonder, then, that coal-rich regions like Silesia and Alsace became prime strategic targets during wars of the nineteenth century.

Winston Churchill's 1913 decision to switch the British Navy from coal to oil triggered a new era of military dependence on energy resources. Hydrocarbon dependency forced states to rely on resources that were usually not domestically abundant in order to ensure their military mobility. As a result, relations with new foreign sources and the logistical links to them became issues of national security. Energy security concerns "went global" as Persia, Saudi Arabia, the Caspian Sea basin, and the East Indies gained new importance, with militaries becoming dependent on oil for their navies and then for tanks, trucks, and airplanes.

European military structures emerged from the First World War much more heavily dependent on liquid hydrocarbons than they had been at the start of the war. The inter-war period saw operational developments that included the development of mechanized warfare and also strategic air power, both of which increased reliance on oil-based fuels.

By the outbreak of the Second World War, military dependence on oil was fundamental to the enhanced mobility and rapid battlefield logistics that marked the new operational environment. This also had implications for strategic planning. Romania, the Caspian basin, and Indonesia became major strategic objectives for the hydrocarbon-poor Axis powers, which effectively shaped major developments of the war. The Japanese bombing of Pearl Harbor was in reaction to the American oil embargo against Japan, which had begun to starve the imperial military machine. Operation Barbarossa overextended German forces and pinned them down deep inside Russian territory, ending in the icy streets of Stalingrad rather than the Caspian oil fields that had been the operation's strategic aim. German research on synthetic fuels struggled to develop alternatives to reduce the Nazi regime's military dependence on oil producing regions.

During the Cold War, significant domestic hydrocarbon reserves on the part of the two superpowers reduced the pressing military need to guarantee access to foreign sources of oil. Thus, the demise of the Seven Sisters' dominance and the wave of nationalizations which swept the industry in the 1960s, while painful, were not resisted with the same zeal which the British (who were militarily dependent on secure imports) had shown for example with regard to Mossadegh. ${ }^{1}$ Still, energy imports continued to play a significant role in military supply - and

Indeed, relatively higher levels of import dependence in Europe continue to pose separate problems with regard to securing access to energy resources. 
whether imported or not, those resources had to be securely and reliably brought into theatre on a regular basis.

Guaranteeing the logistical aspects of fuel provision for military installations was the impetus behind the creation during the Cold War of the NATO Pipeline System, a dedicated fuel supply system for Allied military installations around Europe. In fact, this is a collection of national systems; only in the case of the Central European Pipeline System (CEPS) are the grids actually trans-national. But even at the national level, military fuel supply chains everywhere tended to be marked (unsurprisingly) by a particularly high level of redundancy, and also by significant physical isolation from the civilian market.

Following the end of the Cold War, however, a variety of factors came into play that forced Western military fuel supply logisticians to adapt. Minding fuel costs is nothing new, but the contemporary environment has been marked by three features that combine to exacerbate the challenge of military fuel provision:

- Drastically higher energy unit prices (particularly after 2002) ${ }^{2}$

- Significant post-Cold War cuts in defense spending

- The proliferation of expeditionary missions that require longer and more flexible supply chains.

As a result, a major cost burden is imposed by the consumption of fuel used to move other fuel. In the American military, 70 percent of the tonnage required to position an Army unit is made up of fuel, while the Air Force spends 85 percent of its fuel budget to deliver just 6 percent of its jet fuel usage. ${ }^{3}$ To compensate, planners rely increasingly on local markets, and thus take on the associated cost fluctuations and security risks. This is especially the case in-theatre, where local supplies and logistics chains play an increasingly and remarkably large role in multinational expeditionary missions. U.S. allies are particularly reliant on outsourced fuel supplies, resulting in questionable quality control and supply stability.

Higher prices, along with the cost and danger of in-theatre fuel convoys, also encourage conservation measures (such as speed restrictions or stricter fuel prioritization), which may impact mission effectiveness.

As a result, major fuel efficiency and alternative fuels programs have been instituted by various armed services. The U.S. Air Force, itself the largest single

2 Even after the price collapse in the autumn of 2008, prices remain significantly above the 1980-2000 average. Also, the IEA forecasts indicate the possibility of significant price rises after about 2010 .

3 U.S. Department of Defense, More Capable Warfighting through Reduced Fuel Burden, The Defense Science Board Task Force on Improving Fuel Efficiency of Weapons and Platforms (Washington, D.C.: Office of the Under Secretary of Defense for Acquisition, Technology, and Logistics, January 2001). 
consumer of energy products in the U.S., has also become the largest consumer of renewable energy. Along with its European counterparts, it has taken cues from civilian airlines to maximize simulator-based flight training and fuel-efficient flying, while also developing alternative coal-based fuels to reduce its dependence on oil. ${ }^{4}$ Similar programs across ministries of defense have worked to reduce fuel costs and environmental impact in most NATO member states. The aim is not simply to lower costs, but to move toward a strategic goal of reducing military dependence on foreign oil. ${ }^{5}$ Within theatre, programs have been implemented to increase flexibility as well as reduce consumption. The NATO Petroleum Committee works at the Alliance level to encourage interoperable modular systems for intheatre distribution, and has also promoted such programs as fuel standardization and fuel-additive research to reduce overall fuel consumption during multinational operations.

Despite such efforts, militaries continue to be huge consumers of energy, and hydrocarbons will continue to provide the vast bulk of that energy well into the future. The threat of hydrocarbon shortages to the military will therefore continue to be a potential concern for military planners. Military fuel depots and supply chains are some of the first targets of any operation (especially when air superiority is easily achieved), and on a strategic level embargoes may prevent smaller states from effectively waging war. Indeed, NATO pursued that strategy against Yugoslavia in 1999, and in the developing world blockades to starve an adversary's military machine are still commonly used. ${ }^{6}$ Furthermore, Western military operational costs may be so heavily taxed by wider energy disruptions that the issue of military supply may become politicized, as was the case when Saudi Arabia broke the OPEC embargo to directly supply American troops in Vietnam.

But instances when energy shortages disrupt military functionality to the point of impeding homeland defense are difficult to conceive of, at least among the larger powers. For example, while China considers its oil imports to be a strategic target of U.S. military planners should tensions escalate, analysts tend to assume that China would have sufficient oil to run its military machine in the face of a blockade, even in a time of high-intensity conflict. ${ }^{7}$ The same is undoubtedly true

4 While the benefits of diversifying fuel sources is clear, world coal prices have been soaring alongside oil prices, reaching record levels. Also, some environmentalists argue that this new fuel produces twice the levels of carbon emissions as traditional fuel over the entire production cycle.

5 See the U.S. Department of Defense's Energy Security Strategy, as prepared by the DoD Energy Security Task Force (4 December 2007).

6 "NATO Beefs up Forces, Moves to Block Yugoslav Oil," CNN.com (23 April 1999); available at www.cnn.com/WORLD/europe/9904/23/kosovo.04.

7 Gabriel Collins and William Murray, "No Oil for the Lamps of China?" Naval War College Review 61:2 (Spring 2008): 79-95. 
of most NATO member states, where stockpiles and redundant supply systems exist within the military framework, and sufficient slack in the civilian market can be drawn upon as necessary.

When discussing the contemporary risks to energy security, then, the primary level of security - that relating to the continued existence of the state - is rarely threatened in the developed world. Cost burdens may drive militaries and security services to bear greater supply risk (for example, by relying more heavily on intheatre supply), or they may impact capabilities by crowding alternative investments out of the defense budget and forcing operational limitations. But enough slack normally exists in the civilian market to continue to fuel military and security services in times of crisis, particularly when national security is threatened. As the threat level rises, military priorities are naturally enforced to an increasing degree at the expense of civilian use. Thus, while cost restrictions apply in times of peace and can impose operational burdens, in times of more serious threats to state security those restrictions may be lifted, and even replaced by prioritization measures such as civilian rationing. In order to threaten a state's military functionality, and achieve the kind of energy insecurity that worried planners in the first half of the twentieth century, a systemic cut-off of hydrocarbon resources would have to be particularly drastic.

\section{Energy and Secondary Security: Supporting Critical Domestic Services}

More common, but with potentially grave and wide-reaching implications, are threats to the secondary level of energy security. While stopping short of debilitating the national security apparatus, the lack of sufficient energy provision to critical domestic infrastructure networks can cause the breakdown of a wide range of essential services, from healthcare and safety systems to communication, transportation, emergency response, and basic utilities. Indeed, we can refer here to a "network" of infrastructures, since various nodes are mutually reinforcing. Energy tends to lie at the center of that network, however, due to the necessity of electric power to facilitate the functioning of almost all systems, including the energy production sector that creates electric power.

Different governments have offered varying definitions of "critical infrastructures." In the United States, the National Plan for Critical Infrastructures (NPCI, or PDD-63) defines them as "those systems as assets - both physical and cyberso vital to the nation that their incapacity or destruction would have a debilitating impact on national security, national economic security, or national health and safety." " Those infrastructures can be further divided into critical subgroups. Physical, human, and information assets (like SCADA systems) can constitute a

8 Defending America's Cyberspace: National Plan for Information Systems Protection, Version 1.0: An Invitation to a Dialogue (Washington, D.C.: The White House, 2000). 


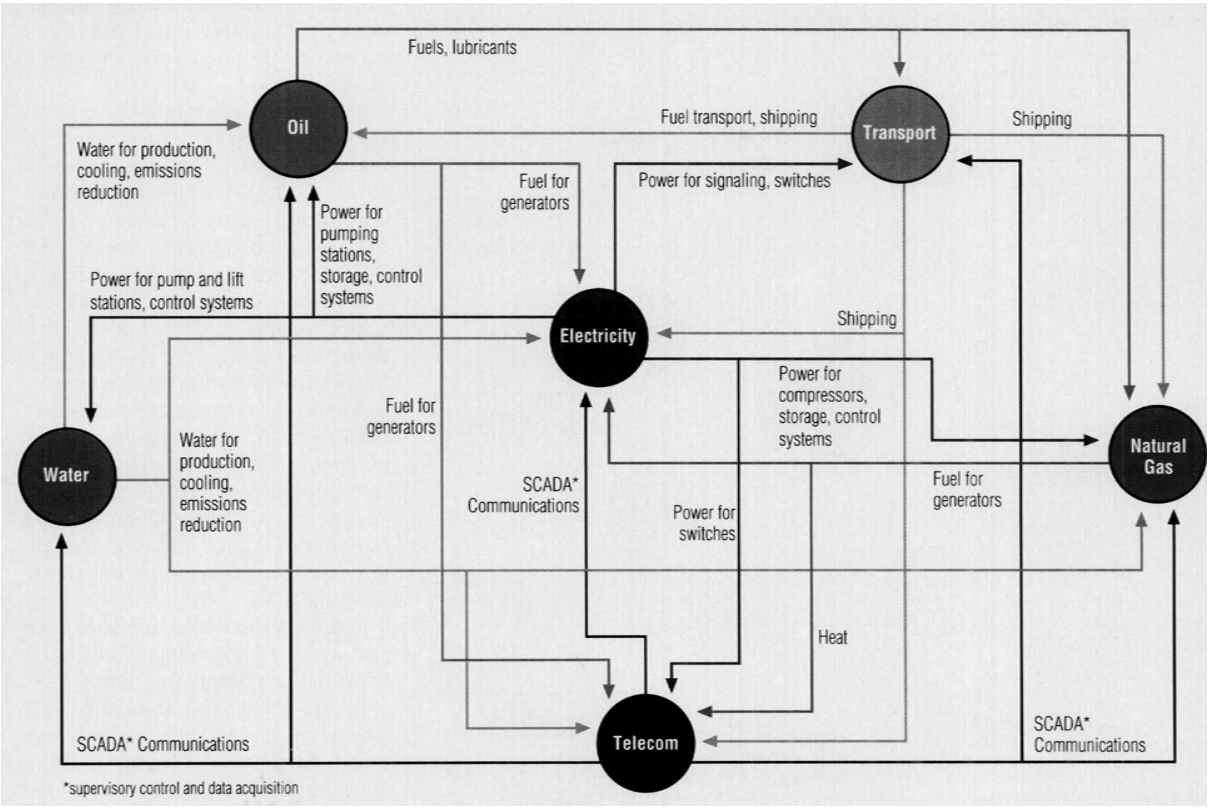

Figure 1: "System of Systems" of Domestic Critical Infrastructures. 9

three-legged stool that supports various infrastructures. They can also be divided into buffered and non-buffered systems, differentiating between physically stored goods and instantly consumed goods and services. Connections between infrastructures may also be physical, cyber, geographic, or logical. Behind almost all of these infrastructure systems, however, is a reliance on energy (and usually hydrocarbon) provision, as depicted in Figure 1.

Determining dependencies and cascading failure modes in critical infrastructures is a complex problem due to such high levels of interconnectedness. Interdependency studies are aimed at identifying these vulnerabilities and analyzing infrastructure-to-infrastructure linkages to determine how localized disruptions can spread. ${ }^{10}$ The problem, indeed, is not simply that the disruption of energy resources can starve the overall system, but that local and limited disruptions can have temporally and spatially widespread effects depending on how, where, and when they occur, as shown in Figure 2 below.

9 Steven Rinaldi, James Peerenboom, and Terrence Kelly, "Identifying, Understanding, and Analyzing Critical Infrastructure Interdependencies," IEEE Control Systems Magazine 21:6 (December 2001): 11-25.

${ }^{10}$ Ibid., 23. 


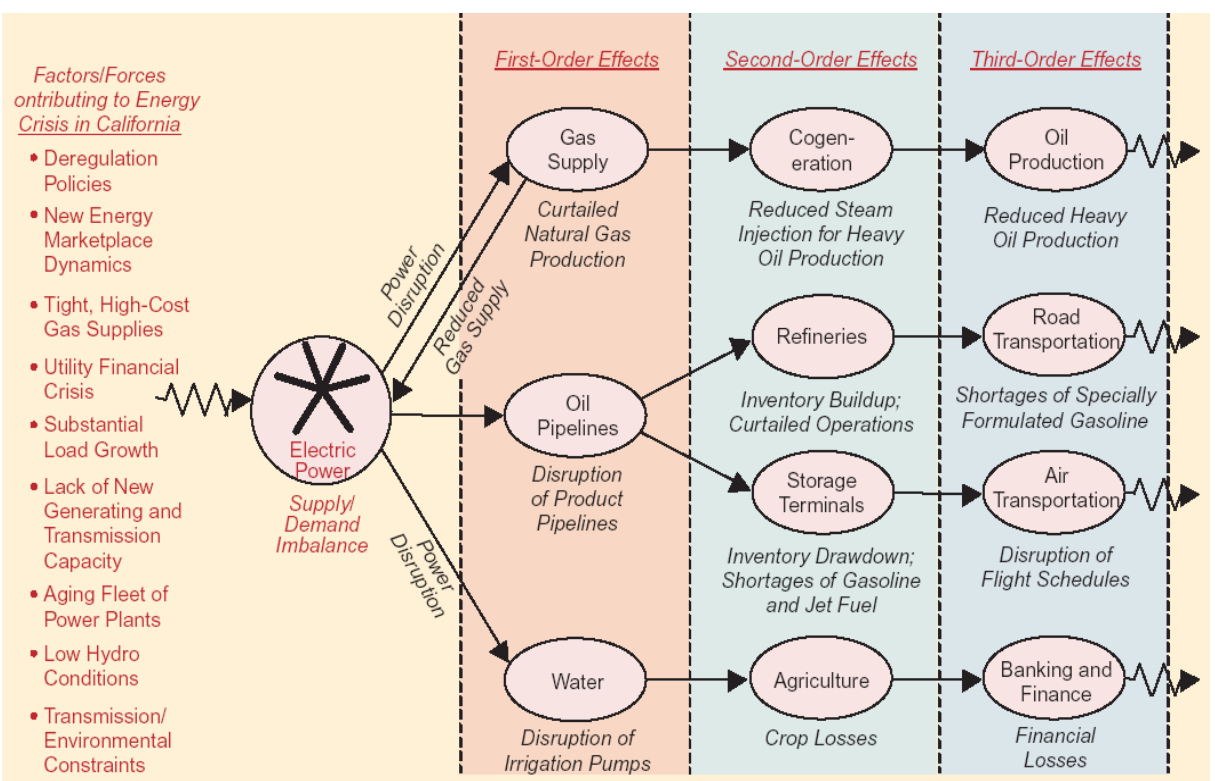

Figure 2: Cascading Consequences. ${ }^{11}$

Major risks to critical domestic energy infrastructures in the U.S. are usually from the result of malfunctions, natural hazards, or terrorism. Indeed, until 2003 the Department of Homeland Security focused almost exclusively on terrorist threats before adopting an "all-hazards" approach to the issue. But for smaller or less diversified states, the possibility of import disruptions (whether intentional or otherwise) can pose severe risks.

Intentional external attempts to pose threats at the level of secondary security by imposing systemic energy starvation are exemplified by the various Russian threats to cut off the supply of natural gas to various nations (including much of Western Europe) over the past three years. Indeed, because of the non-buffered nature of gas, the difficulty of storing it, and its role in producing both heat and power, disruptions to the flow of natural gas represent near-term and potentially deadly risks. While gas provision is not particularly crucial to military functionality, regular deliveries are critical to maintaining domestic services in those economies that rely on it. Thus, the prospect of power outages and heating loss - and the rapidity with which the severity of such a crisis can escalate from negligible to catastrophic - is clearly a powerful force for political coercion.

11 Ibid. 
However, rather than mitigating one's vulnerability to blackmail by confronting the state that poses the threat, it seems more sensible to take such steps as ensuring supply diversity, redundancy, and sufficient fuel reserves; improving civil emergency and consequence management procedures; and building in a greater "cushion" in the logistics chain. In the case of natural gas, it is true that expensive logistics chains (whether pipeline or LNG), as well as fixed long-term contracts, can make diversification or redundancy a prohibitively expensive option. Public sector financing or subsidy may thus provide a level of security that the market fails to offer, by creating incentives for additional investment.

\section{Energy and Tertiary Security: Maintaining Economic Vitality}

As discussed above, the tertiary level of energy security constitutes the need to maintain "reasonable" prices. This means, for consumers, prices that are low enough (and stable enough) so as to allow for the continued economic vitality of the national economy. Between 2002 and 2008, oil prices continued on a more or less constant upward trajectory (despite increasing short-term volatility) due to a variety of factors. Some of these factors were related to actual supply and demand - the latter from rapid consumption increases in the developing world, and the former from insufficient investment in exploration and refining capacity. The U.S. Energy Information Agency predicted in 2007 that each million barrels per day taken off the market would raise prices anywhere from USD 5 to 7 per barrel. Other factors for the rise in prices are rooted firmly in the financial sector, including deepening futures markets (which lead to increased volatility and diminished ability of producers to affect the price), and the dollar's decline. The 2008 price readjustment exposed the misalignment between the real oil market and financial markets, but they continue to play a significant role in pricing.

Tertiary security is the first and most likely of the three levels of security to be threatened by disruptions in the hydrocarbon supply. In the short term, oil and gas price spikes can shock the economy. The empirical evidence from the literature suggests that oil price increases dampen macroeconomic growth by raising inflation and unemployment and by dampening the value of financial assets. Essentially, oil price increases reduce production output and wages, while inducing inflationary tendencies and interest rates, thus reducing aggregate demand. ${ }^{12}$ While the oil-GDP effect is relatively small in percentage terms, producing about 0.5 percent GDP loss for each 10 percent price increase, over time and given drastic

12 Shimon Awerbuch and Raphael Sauter, "Exploiting the Oil-GDP Effect to Support Renewables Development," SPRU Electronic Working Paper No. 129 (University of Sussex: The Freeman Centre, January 2005). 
price changes, the costs can become staggering. One report calculates the cost in the U.S. due to oil price movements between 1970 and 2000 at USD 7 trillion. $^{13}$

In the longer term, sustained high prices can have severe and long-lasting effects on the economy by reducing potential output. The OECD concludes that, going forward, sustained oil barrel prices of around USD 120 could over time reduce potential economic output by as much as 4 percent in the US and 2 percent in the eurozone. ${ }^{14}$ Given the underlying fundamentals, sustained prices at that level or higher were widely presumed when the report was published in early 2008, and are likely to return in the next three to four years. In a Chatham House report published in August 2008, Paul Stevens warned of a forthcoming oil supply crunch by around 2013. ${ }^{15}$ At that point, he predicts a price spike will carry barrel values above USD 200. Such a price for oil would inevitably have a significant macroeconomic impact, despite the apparent resiliency of the global economy in the face of price increases over the past five years.

It is true that since the 1970s the sensitivity of Western economies to oil price fluctuations has been mitigated by a variety of factors. Energy intensity - that is, the relationship between oil consumption and national output-has significantly decreased due to higher efficiency and a move away from manufacturing in the developed world. Technological improvements have also made demand more elastic; capital improvements can more quickly contain energy costs in the face of rising prices. Central bankers' skills at taming inflation have suppressed one of the major macroeconomic nuisances that results from more expensive energy. And improvements in risk bundling and distribution have allowed many firms to hedge against rising energy prices in the medium term.

But especially given the price collapse since July 2008, the energy threat to economic welfare (particularly taking into account that of producers as well) derives not necessarily form higher prices per se, but rather from price volatility. Indeed, the story of 2008 is a good example. The unrelenting oil price increases in the first half of the year constrained central bankers by threatening inflation at a time when they sought to stimulate faltering growth, and the resultant perceived inaction reduced confidence, both of which helped create the conditions for the autumn economic crisis. On the other hand, many producers entered into budgetary commitments that were unsustainable when prices fell past a certain point, leading to policy fluctuations and the possibility of political unrest. Perhaps most

1343 percent due to GDP losses, 31 percent to wealth transfers, and 26 percent to macroeconomic adjustments. See David L. Greene and Nataliya I. Tishchishyna, Costs of Oil Dependence: A 2000 Update, ORNL/TM-2000/152 (Oak Ridge, TN: Oak Ridge National Laboratory, May 2000).

14 "Running Out of Gas," The Economist (13 September 2008).

15 Paul Stevens, The Coming Oil Supply Crunch, Chatham House Report (London: Chatham House, August 2008). 
importantly in the long term, and with the greatest impact on real markets, price volatility seriously impeded investment by increasing the uncertainty of returns for major projects and discouraging the development technologies (or renewable alternatives) that may only be profitable at the margin. Indeed, many operations are simply not profitable to run at today's prices, and have been shuttered —offering a stark warning to future investors.

While tertiary-level energy insecurity may pose less immediate risks to national security, economic rebalancing as a result of changing prices can have significant impacts on the international system. In the most straightforward sense, wealth transfers from consumers to producers (or relative consumer gains when prices decline) are complimented by shifts in political power. At the oil price peak in July 2008, oil producers in the Persian Gulf alone were taking in over USD 2 billion per day from consumers, giving particularly Saudi Arabia a stronger hand in the region. ${ }^{16}$ Windfall budget supplements have also clearly affected the political behavior of states like Russia by boosting political confidence, and have offered a potent foreign policy tool in cases like that of Venezuela.

However, political rebalancing in the other direction is also possible, as occurred in late 2008. Whereas consumers in the U.S. and Europe (particularly Germany, Italy, and Spain) have seen the equivalent of a huge economic stimulus at a crucial moment, many producer nations (especially Iran and Venezuela) find themselves in crisis. Both used their oil windfalls to lavishly fund foreign subsidization (with political strings) and buy off domestic political threats. As those prices collapse, both have discovered gaping holes in their budgets, and are confronted with the need to trim back domestic programs to which their populations have become accustomed. While Russia's large cash savings and moderate social spending during the boom minimized its exposure in that regard, with the reserve having already dwindled by USD 200 billion it will be difficult for Moscow to prudently carry forward the major defense spending increases that it announced in 2007 and 2008.

While the economic effects of energy can reinforce or weaken security policy capability, it can also be a tool in itself-intentional economic warfare (or bribery) can put significant pressure on decision makers to alter security policy. Indeed, the "oil weapon" has been used to punish states for their security policy decisions, beginning with OPEC's targeting of the U.S. and Netherlands for their support of Israel in 1973. Threatening tertiary security through economic warfare is not only limited to state actors. Al Qaeda, which struggles to undermine primary or secondary energy security in the West (so far), has instead based its global oil strategy on inflicting economic pain. Indeed, a recent essay making the rounds on Islamist

16 Peter Zeihan, "Falling Fortunes, Rising Hopes, and the Price of Oil," STRATFOR Geopolitical Intelligence Report (15 December 2008). 
websites titled "Al Qaeda and the Battle for Oil" argues that the organization's strategy rests on bankrupting the U.S. by driving up oil prices by any means necessary. ${ }^{17}$ Again, the intent may not be simply to raise prices as such (particularly given low prices and the relatively short-term price effects of localized terrorist attacks), but rather to cause price volatility in markets. "Volatility reflects fears and expectations," and while individual attacks will likely have a minimal impact on real supply and demand, they can have serious implications for prices as a function of their visibility and severity.

\section{Differentiating Cross-Level Threats and Mitigation Strategies}

Countries may suffer, and can indeed be intentionally targeted by enemies, at all three levels described above. Mitigation at each level requires differentiated approaches, lest insecurity at one level be exacerbated by an attempt to conflate the issues and apply a misguided panacea to energy (and particularly hydrocarbon) scarcity problems. In some cases, instruments of national security (such as hard security tools or the language of military diplomacy) may be effective. Allied efforts to deprive the Axis Powers of a reliable supply of hydrocarbons were certainly instrumental to their demise, and partly defined strategic military goals during the Second World War. Robust physical security also continues to be a major element of protecting infrastructures and logistics chains. However, hard political talk and military force typically engender exactly the heightened risk levels that drive price volatility and impede investment, which can touch all three levels of security. So while specific threat types (grouped here by undesired outcomes) must be assessed within the framework of individual "levels of security," it is important to recognize that such outcomes may derive from each level, however differently.

\section{Short-run Catastrophic Effects}

The first threat-type is most relevant to issues of political blackmail. Potential supply disruptions that portend short-run catastrophic effects put states at particular risk, because by definition they negate the possibility to avert significant losses after the fact. It is therefore easy to apply sharp political pressure.

On what I have described as the primary military level, this would refer to the disruption of energy supply to security services that would impede their functionality to the point of putting service personnel at risk, or that cause military or domestic security operations to fail. That may happen at the point of acquisition, whether due to blockades or other impediments that comprehensively block supply, or within the distribution system, because of failed or targeted infrastructures

17 Chris Zambelis, “Attacks on Yemen Reflect al-Qaeda's Global Oil Strategy," Global Terrorism Analysis Terrorism Monitor 6:17 (September 2008). 
along the supply chain. At the extreme, this could even compromise the existence of the state if it impedes homeland defense.

At the secondary level of civil services, this refers especially to disruptions to electricity or gas supplies at nodes critical enough to cause the breakdown of heating, emergency response, or vital communications. Where a lack of sufficient redundancy or a lack of diversified supply sources create a unique dependency on imported electricity or gas to produce that power, even a short-term disruption can strike at the core of interdependent critical systems. This is particularly the case if consequence management plans are lacking or insufficient.

It seems straightforward that the solutions here are supply diversity, redundancy, fuel reserves, improved civil emergency and consequence management procedures, and a greater "cushion" in the logistics chain. For the military, it also means pursuing greater flexibility through fuel standardization, localized distribution, and reduced consumption, as well as secure logistics chains.

\section{Disproportionate Price Effects}

The second threat-type refers to those events whose prominence or political sensitivity will have disproportionate price effects in the market, and so points particularly to "tertiary level" security, but also to the other levels insofar as they are affected by energy prices. On a wide scale this refers mainly to oil, due to the depth and breadth of that commodity market. Events or threats that markets (rightly or wrongly) perceive to be connected with the security of oil supply are vital indeed because of that perception. Hence, measuring the criticality of certain areas or structures is not simply a function of the volume of product that may be affected, but of the potential impact on market prices.

In this case, effective mitigation requires working with major market players to understand perceived vulnerabilities and factor them into criticality analyses and the prioritization of security aims (rather than simply basing them on product volume throughput). It also means communicating with the market to increase the transparency of security operations with regard to energy infrastructures, and to convey accurate assessments of threats in order to better align market perceptions of physical threats with reality.

\section{Consistently High Costs}

The third threat-type that security policy should consider is that group of threats that impose consistently high security provision or insurance costs on a regular basis. An in-theatre military example is once again that of fuel convoys. The huge costs of securing convoys have caused the U.S. Defense Logistics Agency to turn to autonomous vehicles, local power sources, and conservation.

For private operators, rising costs at existing installations due to increased security concerns - whether due to financial uncertainties or safety risks - can also cause major operational disruptions. One clear example was the declaration of 
force majeure by Shell in Nigeria after being attacked repeatedly by indigenous resistance groups in the Niger Delta in September 2008. Over the past several years, the costs of securing oil operations in Nigeria have steadily risen, not just due to attacks but also to widespread low-level threat and vandalism, and so have come to represent a significant cost of production there. As the price of oil falls, these costs may actually rise. It can be expected that a surge in extortion and bunkering will result from the decreased ability of Abuja to pay off local bosses, particularly in the Delta region. ${ }^{18}$

The same can be said of piracy. 2008 saw a surge in piracy activity off the coast of Somalia, but of greater concern was the pirates' shift toward increasingly brazen tactics at greater range against larger targets. The capture of the Saudi oil supertanker Sirius Star more than 830 kilometers offshore in November 2008 represented a new height of audacity. While piracy has routinely represented a nuisance to global shipping, the upswing of pirate attacks in the Gulf of Aden has exposed the vulnerabilities both in commercial shipping practices and in the mitigation capabilities of Western navies.

In cases such as Nigeria, successful mitigation will usually mean capacity building among host-nation governments to ensure that they have the proper tools to shoulder the security burden expected from the state to provide a secure business environment. However, in the case of Somali piracy, for example-which takes place either in international waters or on the territory of a non-functioning state-military force for limited missions like the ones deployed in autumn 2008 in the Gulf of Aden may be necessary. In those cases, international coordination particularly with regard to determining legal jurisdiction and the legitimacy of the use of force is key. United Nations efforts in that regard at the end of 2008 are thus both telling and encouraging.

\section{Reduced Investment}

Finally, the fourth threat-type refers to security threats that impede investment. Indeed, those might be physical or regulatory threats - and both are important — but for our purposes, investment risk deriving from physical insecurity should be closely considered.

One such example that received extensive press attention in 2008 is the transSahara gas pipeline, a proposed link from Nigeria to the Algerian coast via Niger. It is an interesting case not only because of the competition between Gazprom and the EU to court Nigerian officials over the project, but also because one of the main impediments to the pipeline's construction are physical dangers in each host state (MEND in Nigeria, the Touaregs in the desert, and militants in southern Al-

18 Zeihan, "Falling Fortunes, Rising Hopes, and the Price of Oil." 
geria). If indeed it was decided that this was a public priority project, then providing security assistance at public cost becomes one option to ensure investment.

Other examples such as the Trans-Afghanistan Pipeline (TAPI) or troubles courting investment in Iraq are more familiar.

One major fear is that the so-called "fourth corridor" gains a reputation for insecurity and impedes further investment, including into the Nabucco pipeline from Turkey to Austria. Hence November's explosion on the Kirkuk-Ceyhan line in Turkey and the August closure of the BTC for similar reasons are particularly worrisome. And if we take the August 2008 war between Russia and Georgia over South Ossetia into account, we have to assume that the physical threat posed by interstate conflict with Russia (or over Nagorno-Karabakh) will further impact crucial project development in what was once seen as a relatively safe corridor.

\section{Conclusions}

This article has attempted to categorize energy security risks in the context of security policy by differentiating threats to military functionality (primary level), critical domestic services (secondary level), and economic vitality (tertiary level).

At the primary level, the first step to mitigating risks is the classic one of aligning national security priorities and financial realities. In developed economies and among modern militaries, budgeting for fuel costs assumes a wide range of scenarios and is sometimes supported by hedging strategies to reduce uncertainty. ${ }^{19}$ However, over the longer run, higher fuel prices will have a serious impact on military functionality, and mitigating that risk requires first and foremost demand management. A 2007 study ordered by the U.S. Department of Defense warned that the rising cost of oil would make America's ability to respond to global crises "unsustainable in the long term." ${ }^{, 20}$ Across the U.S. military, and particularly within the U.S. Air Force, a recent focus on efficiency and conservation has brought the issue of demand to the forefront.

At the sourcing level, though, relying on market prices means that violence that may drive energy prices higher can negatively impact functionality through higher cost burdens; thus, employing force to acquire energy products is often counterproductive. Where state existence is threatened, however, and military necessity demands further resources, prioritizing fuel usage for military purposes becomes standard. The process is usually legislated. One example is the Australian Liquid Fuels Emergency Act (1983), which restricts the amount of fuel available for military missions in the case of supply disruptions unless the homeland is threatened, in which case the military is given top priority.

19 In the U.S., hedging for military fuel budgets is actually discouraged, presumably to avoid political embarrassment if the hedge is pegged too high.

20 "Pentagon Study Says Oil Dependence Strains U.S. Military," Boston Globe (1 May 2007). 
Thus, it is unlikely under contemporary circumstances that defensive operations are likely to be hampered by fuel shortages to the point where the national territory is at risk. Exceptions of course exist in fuel-poor countries that face sustained military pressure on state security forces and are characterized by low peacetime levels of domestic hydrocarbon consumption, providing very little civilian "slack" that could be redirected to the military. Beyond prioritization, the prospect of resource seizure or the annexation of production facilities through force may become a viable option. Resource wars over hydrocarbon stocks may indeed solve limited short-term supply issues, but they are more classically driven by the prospect of economic rather than strategic or military benefits.

Threats to secondary security have garnered particular attention recently, particularly with regard to natural gas. Increasing reliance on gas networks for power generation and heating, the relative paucity of suppliers, and the difficult nature of gas transport can bind countries into co-dependent relationships that carry over into the political and security arenas. The challenge of storing natural gas, and also its widespread impacts on crucial everyday functions, necessitates secure and sustained supplies.

When it comes to mitigating this type of insecurity, encouraging diversification and limiting political (particularly foreign state) ownership are the products of smart regulation and targeted incentives that reduce vulnerability in the medium run. In the short run, domestic security services should work to identify and protect the most critical infrastructures, and emergency management agencies should formulate disaster plans. In the event of cut-offs that carry the potential for humanitarian catastrophe, concerted international support and relief efforts may be required.

But if our aim is to maintain reasonable and stable prices in a global market, military instruments (except in very specific and tailored applications) are more often than not counterproductive. The potential for military action has a potent ability to scare both traders and investors. Estimates are fuzzy, but fears of violence may add more than USD 30 in premiums to the per-barrel price of oil. Gas is an altogether different story, as prices are negotiated over longer periods and are highly influenced by transport difficulties. But here too the investment and regulatory environment drives security of supply much more than saber-rattling. With these kinds of complexity, confusion is understandable.

But it is dangerous to assume that issues that impact national security should all be addressed with instruments of security policy, such as military assets or NATO action. The crises of the 1970s demonstrated that increased transparency and functioning markets are the keys to ensuring a secure supply of energy, and indeed the U.S. Energy Information Agency was created for exactly that reason. "Militarizing" energy politics threatens tertiary security by sending the wrong signals to the market and to potential investors in infrastructure projects, whether 
they are state-owned monopolies or not. Vague and threatening comments (like aggressive rhetoric towards Russia) do not make traders confident, or national oil companies (international oil companies, for that matter) more willing to increase capacity, thus reducing energy security in the short and long run respectively. If sufficiently exacerbated, secondary and even primary energy security could be put at risk.

It is important to note that the changing nature of the hydrocarbon marketparticularly deregulation and privatization in Europe- has eroded national champions and merged the secondary and tertiary levels together. Societies rely largely on market mechanisms to deliver energy products to public services, including the military. High fuel bills eat into set budgets and crowd out alternative investments.

All this is not to say that "hard power" has no role in promoting secure and sufficient energy flows. Supporting infrastructure security where requested and keeping shipping lanes safe do improve the economic environment. And, most important, sharing security information through training, surveillance assistance, and intelligence cooperation boosts security capacity through transparency. Military tools can be effective in helping guarantee physical security, and managing their use precisely can be effective in reassuring those actors that hold the power to influence prices. But swinging the blunt instruments of security policy more wildly is not the way to guarantee energy security in today's environment. 


\section{Bibliography}

Awerbuch, Shimon, and Raphael Sauter. Exploiting the Oil-GDP Effect to Support Renewables Development In SPRU Electronic Working Paper. University of Sussex: The Freeman Centre, 2005.

Collins, Gabriel, and William Murray. "No Oil for the Lamps of China?" Naval War College Review 61, no. 2 (2008): 79-95.

Defending America's Cyberspace: National Plan for Information Systems Protection, Version 1.0: An Invitation to a Dialogue. Washington, D.C.: The White House, 2000.

Energy Security Strategy In by the DoD Energy Security Task Force. U.S. Department of Defense's, 2007.

Greene, David L., and Nataliya I. Tishchishyna. Costs of Oil Dependence: A 2000 Update. Oak Ridge, TN: Oak Ridge National Laboratory, 2000.

More Capable Warfighting through Reduced Fuel Burden, The Defense Science Board Task Force on Improving Fuel Efficiency of Weapons and Platforms. Washington, D.C.: U.S. Department of Defense, Office of the Under Secretary of Defense for Acquisition, Technology, and Logistics, 2001.

NATO Beefs up Forces, Moves to Block Yugoslav Oil. CNN.com, 1999.

Pentagon Study Says Oil Dependence Strains U.S. Military. Boston Globe (2007).

Rinaldi, Steven, James Peerenboom, and Terrence Kelly. "Identifying, Understanding, and Analyzing Critical Infrastructure Interdependencies." IEEE Control Systems Magazine 21, no. 6 (2001): 11-25.

Running Out of Gas. The Economist (2008).

Stevens, Paul. The Coming Oil Supply Crunch In Chatham House Report. London: Chatham House, 2008.

Zambelis, Chris. "Attacks on Yemen Reflect al-Qaeda's Global Oil Strategy." Global Terrorism Analysis Terrorism Monitor 6, no. 17 (2008).

Zeihan, Peter. Falling Fortunes, Rising Hopes, and the Price of Oil In Geopolitical Intelligence Report. STRATFOR, 2008. 